\title{
Does Autobiography Matter?: Fictions of the Self in Aleksandar Hemon's The Lazarus Project
}

\begin{abstract}
In this article, I examine Bosnian writer Aleksandar Hemon's relationship to and intervention in life-writing. Hemon's fiction provides rich terrain for exploring the key shifts and obstacles facing the genre(s) at present by crossing national as well as aesthetic borders. In doing so, I trace his first autobiographical gestures in his earlier fiction against his recent insistence that his stories are "antibiographical" since they are the very "antimatter to the matter of my life. They contain what did not happen to me" - thus, an alternate, unrestrained space in which Hemon can flesh out multiple fictional selves. With his novel, The Lazarus Project, he delivers, in essence, a fictional biography on two levels: a main narrator (Brik) who enacts the author's own exodus but also traces and retells an immigrant stranger's past (Lazarus) in order to work through his present conflicts, anger and sadness. The novel's tensions between biography, autobiography and photography emerge from what Hemon calls a "conditional Americanness" that has overtaken the American Dream. Hemon employs photographic imagery not only to refute given notions of history and archive but also to craft a narrative imagination that builds on late German writer W. G. Sebald's own transgressions within (auto)biographical writing, yet targets and questions more American and cross-cultural identity categories.
\end{abstract}

Key words

Autobiography; photography; Aleksandar Hemon; intermediality; immigrant identity; W. G. Sebald; photo-fiction; genre hybridity

To my mind, my stories are not autobiographical; they are antibiographical, they are the antimatter to the matter of my life. They contain what did not happen to me.... 
During several interviews for his recent story collection Love and Obstacles (2009), Bosnian writer Aleksandar Hemon makes rather dismissing remarks concerning memoir and autobiography as vital literary genres. Fending off the autobiographical tagline usually put on his work, Hemon seemingly offers a limited understanding of these genres as being nearly synonymous with or dominated by confessional mode - a style that, at least for Hemon, leaves little to the imagination or engages the reader only on voyeuristic terms. While he, like many other writers, starts from a "personal space," he must supplement and hand that experience over to a "construction that is no longer mine, that is not me" (Reyn 2010), "effectively losing the notion of contained selfhood that would resemble me" (Johnson 2010: 20). Yet, Hemon clearly makes little effort to demarcate his own experiences as an immigrant in America (who arrived and settled in Chicago in 1992) from those of his narrators, other than providing different names; they continue to resemble one another quite intimately, regardless of an insistence that "they [his stories] are the antimatter of my life" (Kaiser 2009). Over much of the last decade, Hemon has perfected protagonists that cling closely to his own life trajectory while, at the same time, jettison off into their own fictional spheres, leaving the reader all the more anxious to somehow certify that identification bind. With his novel The Lazarus Project, Hemon delivers, in essence, a fictional biography on two levels: the main narrator (Brik) who enacts the author's own exodus but also traces and retells an immigrant stranger's past (Lazarus) in order to work through his present conflicts, anger and sadness. However, I would like to reconsider Hemon's apparent rejection of autobiography (as mostly testified in interviews) and how it works in tandem with the strong biographical impulse driving his fiction. I would argue that Hemon's proclivities are more acts of caution against what might be lost when these genres become too rigid or familiar, and thus, immune to the transgressions that keep such aesthetic debates viable. For, as much as he questions the literary merits or intentions of autobiography as genre, it is clear that he cannot entirely escape their horizons either, nor really wishes to: "All the lives I could live, all the people I will never know, never will be, they are everywhere. That is all that the world is" (Hemon 2008: 2).

The project of self-representation remains central to Hemon's writing as he persistently targets that space between national identities and cross-cultural trajectories and contemplates transnational possibilities by way of individuals who fall into the author's own flight patterns. Moreover, many of these characters are themselves marked, if not obsessed, by an "auto/biographical demand," by which an individual tells his or her story through others (Gilmore 2001: 72). As Gilmore has argued, this method often occurs in instances of trauma when "the portals are too narrow and the demands too restrictive. [...] In this scenario, the autobiographical project may swerve from the form of autobiography even as it embraces the project of self-representation" (2001: 3). In The Lazarus Project, however, the narrator Brik's auto/biographical impulses in pursuing Lazarus's story do not emanate from traumatic experience, but rather its disturbing absence or removal - or, to be more precise, feelings of guilt at not having witnessed 
events firsthand. ${ }^{2}$ (This aspect will be returned to later when considering Sebald's narrative strategies and ethics.) Brik, like Hemon, left Bosnia-Herzegovina in early 1992 for a one-month cultural exchange programme in Chicago, but with the war breaking out during his visit, he was prevented from returning home and forced to watch his homeland strife unfold through 24-hour CNN frames: "I who had left just before the beginning and missed the whole shebang. [...] [It was] my inability to understand what it was really like" (Hemon 2008: 18). Consequently, he avoids, for the most part, conversations with fellow Bosnians that would lead him to question his stake in this shared knowledge, to realise that he, in fact, had missed "the best parts" (19), or much like Jozef Pronek's (another alter-ego character) resignation when "he only watched the images to recognize the people in them" (2001: 171). Brik's "Lazarus project" thus becomes a construct by which he draws upon historical, personal and fictional elements in a self-effacing manner. When he first confesses his desire to trace Lazarus's footprints to America, he could easily be speaking of filling in a recent Sarajevo past: "I needed to reimagine what I could not retrieve; I needed to see what I could not imagine. To spend time in the wilderness of elsewhere" (Hemon 2008: 46). Brik emerges as an unknowing biographer - yet, one who imagines, revises and assembles Lazarus's life details not under any documentary expectations, but instead, to create new narrative forms that precisely allow for that elsewhere, without forsaking the present somewhere or ending up in nowhere.

The Lazarus Project offers parallel narratives of immigration to Chicago by two Eastern Europeans set nearly one hundred years apart - the first one in 1908, and the second, present day. In the first case, Lazarus Averbuch, a young Ukrainian-Jewish immigrant who has survived the pogroms, arrives in Chicago to start a new life only to be shot and killed after being a suspected member of an anarchist conspiracy. ${ }^{3}$ In the second, Vladimir Brik, a Bosnian writer who has unintentionally escaped the civil wars in Yugoslavia and now made a home in Chicago, becomes infatuated with Lazarus's case more than ten years on - finding many resonances but also discovering how much Lazarus complicates Brik's own ideas about assimilation and exclusion and what Hemon has referred to as a certain "conditional Americanness" (Kaiser 2009) that now operates in place of the American Dream. He longs "to be immersed in the world as it had been in 1908, [to] imagine how immigrants lived then ... I had to admit that I identified easily with those travails [and] the ennoblement of self-fashioning" (Hemon 2008: 41). After acquiring adequate funding, Brik undertakes a research trip that leads him back to Eastern Europe and Lazarus's origins but also to visit a post-war-torn Sarajevo. On a whim, Brik brings along a long-lost Sarajevan friend he stumbles across in Chicago at a Bosnian Independence Day event, Ahmed Rora, a scam artist and photographer who documents the trip and tells endlessly entertaining, though greatly exaggerated war stories. To further ally the author with narrator, Hemon himself took this same trip after receiving the MacArthur Foundation "genius grant," along with a good friend, Velibor Bozovic, who is a photographer and whose photographs of the trip are interspersed with the historical pho- 
tographs of Averbuch and others, compliments of the Chicago Historical Society. The novel is as much a story of Brik and his attempt to visualise Lazarus's story as it is a narrative devoted to justifying/resurrecting Lazarus. Thus, The Lazarus Project scrutinises how these histories are not only represented and constituted as visual and textual archive but also potentially re-imagined by future generations.

Juxtaposition lies both in the novel's subject matter and form. The two century-apart narratives weave back and forth across one another, alternating chapter by chapter, while, at another level, both texts are paced by photographs from 1908 and the contemporary context - images which cannot so easily be differentiated from one another (due to the spectral nature of many of the contemporary images) much like the intertwined stories themselves. The novel proper begins with Lazarus's entry and swift departure when he is murdered after attempting to deliver a letter to the Chicago chief of police George Shippy - an act in its oddity that was immediately interpreted as threatening and befitting politically uncertain times. In doing so, Hemon sharpens an obvious rapport between early twentieth-century ethnic conflicts and the xenophobic hysteria of a twenty-firstcentury America in which both societies operate on significant levels of fear, violence and discrimination, far more than most people would care to admit. ${ }^{4} \mathrm{He}-$ mon confronts a national consciousness incited by news media and our conflicted canvas of truth-telling (reality) and story-telling (entertainment) - a scenario that is equally problematic in both contexts: "Freedom is a business much easier to run if the authorities have a useful enemy, and anarchists appear to be more than happy to be cast in that role," one character explains (2008: 145). Yet, the novel would not work quite so well if Hemon adhered to a trite parallelism of then versus now, or by Brik merely retelling Lazarus's story outright. Instead, Hemon blends and obsesses quite noticeably about the possibilities of this blending. This can be seen in how the reader is thrown straight in to the gritty sensationalism of 1908. Brik begins by stating the only facts he knows "March 2, 1908, Chicago" - and moreover, the only bits of certainty within the novel as a whole. However, with this disclosure, Hemon initiates an investigation of the language and politics of archive (visual and textual) and historiography that underscores the entire text. For example, in this opening scene (and other early sections of the Lazarus narrative), Hemon italicises certain words or sentences to mimic and problematise the news journalism of that time - best signified by the Chicago Daily News's "first pen" William Miller - being taken as objective record. He configures Miller as an early New Journalist in tone - clearly riding a subjective wave and yet, someone who hopes to gain historical accuracy by emotive verse not witness: "Throughout the struggle," William P. Miller writes, "the anarchist had not uttered a syllable. He fought on doggedly with that cruel mouth shut tight and the eyes colored with a determination terrible to behold. He died without a curse, supplication or prayer" (2008: 9). In Brik's own sections, he sometimes delivers two versions of the same story, not necessarily to contend with each other but to exist in their doubleness, without seeking to authenticate or make value judgments: "There are so many stories that could be told, but only some of them are true" (Hemon 2008: 
100). These heterogeneous elements make the work difficult to categorise as Hemon crafts an intriguing tension between fiction and non-fiction, imagination and fact, photographs and text, and biography and autobiography.

However, Hemon is no stranger to the autobiographical. His first two books were critically well-received exercises in genre hybridity: The Question of Bruno (2000), a collection of semi-autobiographical short stories quietly linked to one another, and Nowhere Man (2002), essentially a novel but one that repeatedly switches narrator frames. The Question of Bruno, his first work in English, utilises different auto/biographical strategies to blur these lines and craft a kaleidoscopic view of history and identity, fact and fiction, present and past. ${ }^{5}$ In this collection, Hemon is more reflexive and direct with such impulses in the text, especially in the story "Exchange of Pleasant Words" which revolves around a long-awaited Hemon family reunion and comments upon the "Hemoniad" problematic at large: "The trouble with the Hemons [...] is that they always get much too excited about things they imagine to be real" (Hemon 2001: 114). Despite these openings, the stories are primarily devoted to fictional agendas while any autobiographical elements are reconstituted to point out the dangers in believing history to be infallible. The story "The Accordion" most lucidly signifies this motivation. In this story, Hemon places his own relative (his great-uncle) at the centre of the Archduke Ferdinand's assassination in Sarajevo 1914, and closes by crisscrossing temporal and spatial differences: "Uncle Teodor is now stuck in the Serb part of Bosnia. Most of my family is scattered across Canada. This story was written in Chicago (where I live) on the subway, after a long day of arduous work as a parking assistant, A.D. 1996" (Hemon 2001: 92). On the one hand, "The Accordion" extends ostensible facts about his family and own daily labours, and, on the other, it remains an anecdote about an accordion-playing ancestor who is most likely fictitious and unverifiable. Everywhere in these stories are instances of acute observation, which are couched in the many parenthetical interjections running through the stories, and more often surveillance, which are marked by cameras or recording equipment themselves. Somewhere is the lingering presence of a fixed, all-knowing perspective. Yet, in Hemon's universe, we are continually caught between a definite view of history as it stands and a more imaginative retelling of events per individual or even familial interjections, as can be best glimpsed in the story "The Sorge Spy Ring" in which a main factual story and its accompanying footnotes compete for the reader's full attention. Hemon never glosses over which narrative triumphs in the haziness of his stories; nevertheless, this does not detract from his interrogation of History itself. ${ }^{6}$

Critic James Wood of The New Yorker has likewise assessed Hemon's approach to the autobiographical in his fiction as follows:

He likes to use his family name in his fiction, and to refer recurrently to certain relatives and family histories, but the autobiographical veracity of that fiction seems architectural rather than foundational. More than any other American novelist I can think of, he has made a kind of running autobio- 
graphical fiction of his actual circumstances - the childhood in Sarajevo, the exile in America, the early hardships in Chicago. He is a fabulist but not really a postmodernist; or, rather, he is a postmodernist who has been mugged by history. (2008)

While Wood argues for autobiographical traces, he implies that it is ultimately more a matter of stylistic overlay or performance than guiding substance that leads Hemon to this threshold. Wood thus seeks to situate Hemon amongst the likes of Donald Barthelme and Robert Coover, for example, whose ingenuity and versatility in their short fiction emanated greatly from pseudo-autobiographical, ironic narrators and the lustre or fantastic spectacle they could spin out of an everyday encounter or mundane details of life. Indeed, as much as Nabokov and Sebald are highlighted as Hemon's closest forefathers, there is, I must agree, a telling connection with this fabulist strain in American fiction that Hemon digests but tweaks to fit his own needs. He is able to move from the playful intimacies of pseudo-memoir to the hyperrealism of sniper streetscapes and a melancholic awareness of history and exile, allowing the language itself to provide fluency rather than idea-content. ${ }^{7}$ Yet, his prose also churns on a heightened appreciation of the language as a relatively new non-native speaker, with unusual words and phrases and refreshing cadence - hence, again eliciting similarities to Nabokov. However, in returning to Wood's above points, I would have to disagree that Hemon's autobiographical endeavours are products of style over substance, the décor and polish rather than the framework. It cannot be overlooked the extent to which Hemon pits fact against fiction, the real with the unreal, not simply for nuance or effect but more to mine a narrative imagination, one which he feels is dissipating in American social and literary landscapes. This disparity is best revealed in Brik's admiration for the pleasure Bosnians take in inventing stories versus the truth-thirsty culture he has become accustomed to: "Disbelief was permanently suspended, for nobody expected truth or information, just the pleasure of being in the story and, maybe, passing it off as their own. It was different in America: the incessant perpetuation of collective fantasies makes people crave the truth and nothing but the truth - reality is the fastest American commodity" (Hemon 2008: 103).

It is worth noting that Brik signals a discernible departure from the edgier, more sardonic characters in Hemon's earlier fiction, showing Brik fumbling far more furiously and miserably with the cross-cultural (and cross-continental) impasse that occupies nearly all of his work. Hemon even cautions that "Brik is who I could have been. I become other people in writing. Though Brik is closer to me for obvious reasons, I give parts of me to all my characters, and they take that and live as themselves" (Baker 2008). Another narrator/character Jozef Pronek, who debuted in the main novella ("Blind Jozef Pronek and Dead Souls") of The Question of Bruno and reappears in Nowhere Man, arrives from Sarajevo in January 1992, spending most of the coming days, months and years beleaguered by minimum-wage scrapping in Chicago; Pronek goes through patches of immense 
isolation and alienation, reminiscent of Ellison's own narrator in Invisible Man: "He realized that he was invisible, and he desired being watched - he imagined a camera that would always follow him everywhere and record all the inconsequential and infinitesimal actions of his life" (Hemon 2001: 195). Yet, Pronek makes healthy-enough strides by the end and decides to return home "because he realized it was all right" and that "you could never be nowhere, because there was something everywhere" (2001: 203) - having lost any fears about falling through the cracks of the past or into some future liminal space. In contrast, Brik appears relentlessly worn out by juggling his double citizenship (Hemon 2008: 11), wanting to feel at home in America and in his marriage to Mary whilst dreaming of being elsewhere. He loves America in many ways, where "there is no space left for useless metaphysical questions" or no "parallel universes" since "everything is what it is" (206), but nonetheless remains sceptical of the edifice (if not artifice) of that reality. Mostly for Mary's happiness and the desire to fit in with the more established hyphenated identities around him [his wife's family is staunchly Irish-American and secure that bond and their "Irish roots [by] imbibing stout" (40)], Brik tests out his "Americanness" at times. For example, when trying to transcribe the vast Ukrainian terrain into letter form for his wife, he notes that "one feels so small in this place. This must be how settlers felt facing the prairie" (110). Yet, Brik's attempt to assume the frontier gaze fails in this moment since he is more swallowed up by the scene than incited by the manifest possibilities of that scale, overlooking the myths of manifest destiny. Hemon details the complicated process of becoming American for a man who relishes in being "complicated" (15): "Mary could only see my American face, acquired through failing to be the person I wanted to be" (106). Instead, Brik waits for when "what is real becomes unreal, what is unreal becomes tangible, and all [his] levelheaded efforts to keep a tight ontological control are rendered silly and indulgent" (48).

The Lazarus Project, therefore, confronts us with a portrait of cross-cultural identity no longer understood as that "nowhere" zone between two known or better places, but rather one that embraces both equally, if not multiple possible homes, as Hemon himself explicates: "I'm actually in two places at the same time, which is different. Despite what my characters feel and do in my books, I don't feel so metaphysically displaced that I'm nowhere" (qtd. In Reyn 2010). In this way, Hemon strikes a new tone for immigrant writers who are moving away from previous models far too dependent on securing hyphenated identities, the "neatness of [an] immigrant story" (2008: 18). Instead, he, by way of Brik's own designation, purports himself to be a "double citizen" (11), or more multitudes as his penchant for a well-stacked syntax of semicolon sentences echoes his desire to keep supplementing not selecting:

I am an American and Bosnian writer and I like to think that what happens in my books and in my life is that those two spaces overlap. They overlap through the experience of immigration and diaspora, and they also overlap because I want them to overlap - I write about people who are finding ways 
to live in the States because their life is defined by their Bosnian experience. [...] So this multiplicity of identities or double identities, these are not necessarily mutually exclusive and they don't create a vacuum but rather create an overlapping space where interesting things happen.

(Reyn 2010, my italics)

This critical overlap can be glimpsed in one emerging credo from the novel, voiced through Lazarus's persona early on: "There has been life before this. Home is where somebody notices when you are no longer there" (Hemon 2008: $3)$. Brik tackles the tendencies to evacuate or erase one's homeland or memories upon arrival, even if they are inevitably caught up with traumatic events. Hence, he specifically retains the present tense: "There has been life before this" marks a desire to bring forward experiences into the present moment rather than sacrifice or shrug them off entirely, which Brik later pictures for the crowds who pass through the threshold of Ellis Island (160). Likewise, "home is where somebody notices when you are no longer there" signals simultaneity, an absence felt in one place that nonetheless registers as a presence elsewhere; home frequently operates as double presence within Hemon's fictional aesthetic. Hence, his earlier motivations to write Lazarus's story - to take up one firm identity and quit his "moral waddling" and mediocrity - will falter: "The book would make me become someone else, go either way: I could earn the right to orgasmic selfishness (and the money) or I could purchase my moral insurance by going through the righteous processes of self-doubt and self-realization" (133). Brik suffers the frustrations of being in the middle but can neither fashion himself into a BosnianAmerican, nor an all-or-nothing American. This doubling of home (and identity) also forces Brik to realise that he cannot abide by any strict, often self-induced, divide between former and present self, history and present, archive and memory. For example, he is notably disturbed when he revisits Sarajevo and is unable to see its newness, the efforts made by the city to move forwards. He can only observe traces of the old: "I walked among the prettied-up ruins and bullet-riddled facades, and saw what they used to be, not what they were now. I X-rayed through the visible and what I saw was the original past version" (208).

While both Pronek (Nowhere Man) and Brik return home in their respective tales, Brik leaves the narrative distraught and unable to finish his letter to his wife, explaining that he has decided to stay in Sarajevo "until I sort myself out" (Hemon 2008: 287). But, more unsettling is the fact that he may have merely traded one place and divide for another, forgetting Lazarus's call for continuity between the present and the past, that "there has been life before this" (3) without losing oneself in that recall. Instead, Brik leaves us with this break in communication: "I cannot remember what my life used to be, how I got to this point. I don't know where everything disappeared. I think I might stay in Sarajevo for a while" (287). In doing so, Brik resembles the narrator at the end of Sebald's The Emigrants who likewise returns to visit his homeland, all the more aware of the amnesiac void in history and how memorialising becomes a more difficult venture 
after living abroad. Nevertheless, Brik feels he must experience a loss of self to move forwards. Through speculating and replaying Lazarus's small triumphs and failures, he had hoped to find better insight and access. It is Lazarus's incapacity to break into the American mould that prompts the narrative and likewise Brik's own decision to remain in Sarajevo, as Hemon explains:

I have always been bothered by the American dream mythology. It is inherently assimilationist and it entirely denies all the exploitation, injustice, and loss that immigrants experienced upon arrival here. [...] Immigrants had to forget about what they left behind and pass through all this hardship - as though an unlivable wage were a way to teach them how to be American - and finally become human by virtue of becoming American. Those who could not, did not, or would not adjust and accept the conditions of being American have been eliminated from the story of the American dream.[...] That's what happened to Lazarus; he did not and does not fit into the story of the American dream. (Baker 2008)

Likewise, Brik discovers more missing than gained:

I used to tell stories to Mary, stories of my childhood and immigrant adventures, stories I had picked up from other people. But I had become tired of telling them, tired of listening to them. In Chicago, I had found myself longing for the Sarajevo way of doing it - Sarajevans told stories ever aware that the listeners' attention might flag, so they exaggerated and embellished and sometimes downright lied to keep it up. You listened, rapt, ready to laugh, indifferent to doubt or implausibility. There was a storytelling code of solidarity. (Hemon 2008:103)

Brik's journeys elsewhere force him to realise how much his life had become "neatly divided" between Sarajevo and America, and how that space for imagination, for stories that do not have to be always logical, purposeful or truthful, for that overlap of confusion is really what he misses and needs the most.

$$
* * *
$$

For the purposes of this article, I am most concerned with the question of how Hemon (through Brik's guise) handles and represents Lazarus's story, and moreover, the necessity of making it a story in all its fictional virtues. After all, it is the continuous reimagining and questioning of any factual foothold that constitutes the crux of the work. But, it is also the strange allure of writing and imaging Lazarus's biography which affords Brik's deepened understanding of his own struggles with homeland memories, past traumas and present realities. For this reason, I wish to examine the role photography assumes with regards to the narrative's auto/biographical elements. Not a commonplace practice, using photo- 
graphic images within a story naturally lends non-fictional connotations to the work, regardless of an overwhelmingly fictional register. Therefore, it is little surprise that photography sports a remarkably similar history to that of autobiography itself, particularly in its equally problematic referentiality, and resilient assumptions to locate the authentic or accurate in photographic likeness. Timothy Dow Adams traces this affiliation between autobiography and photography, life writing and light-writing, emphasising their unique status to each other and the external world:

Autobiography is a form of narrative characterized by a desire both to reveal and to conceal [and] as a result, its power comes from [...] the indeterminacy of its sense of reference to the world. The fact that life writing and light writing, both by definition and common perception, have a strong felt relationship to the world, a relationship that on examination seems to disappear, is paradoxically what gives both forms of narration their unusual strength because this situation parallels the way all language works. (Adams 2000: 15)

Rosalind Krauss reiterates photography's essential distinction from other visual/ artistic mediums, drawing upon Andre Bazin's earlier insistence on the indexicality of all photographs: "No matter how fuzzy, distorted or discoloured, no matter how lacking in documentary value the image may be, it shares the being of the model of which it is the reproduction; it is the model" (qtd. in Krauss 1993: 203). Therefore, it is understandable that photographs might "rub off" their traces of the real (or for Barthes, the "thing-that-has-been") onto the fictional context surrounding them. However, this referential gesture toward documentation cannot be taken for granted, since in Hemon's case - and for that of much contemporary photo-fiction as Adams has recently suggested $(2008)^{8}$ - the accuracy of narrative or the "facts" of Lazarus's case are not reinforced or even developed by the accompanying images. Indeed, as the Lazarus narrative continues, it becomes less entrenched in physical realities and the idea of resolving Lazarus's case at all, and more dreamlike and escapist through Olga's musings. Nor does Brik's journey through Lazarus's deserted landscapes become any clearer with those images by Rora (Bozovic) included in the novel. Instead, the ambiguous (at times indecipherable) nature of the photographs and their incorporation complicates the text and generates indeterminacy. Although the presence of certain images (the two death-pose portraits of Averbuch, for example) serve to bolster Olga's tragedy and more obviously, seize the reader's attention from the beginning, many of the ensuing images undercut the prose and force the reader into a more discerning role. Either the seeming randomness, arbitrariness or historicity of the images pushes the reader to posit and then readjust their expectations of how image matches (or does not) with the text. As aptly described by Mary Price, this is often the paradox when photography appears in autobiographical frames: "What is said about a photograph depends on what is perceived by the viewer, who must, according to the use intended for the photograph, resolve, explicate, or ignore the 
significant tension between heightened by life and paralyzed by fact"' (Adams 2000: 172).

Hemon was drawn immediately to the startling photographs of Averbuch, which were published at that time in the now-defunct Chicago Daily News. Photography, the camera and the role and responsibilities of the photographer, encapsulated mostly in the character of Rora, are all significant features in the book, with the images working to interrogate a kind of documentary factuality along the lines of W.G. Sebald's post-World War II novels (The Emigrants, The Rings of Saturn, Vertigo, Austerlitz). ${ }^{9}$ For Jonathan Long, Sebald's strategy is largely an "ontological hide-and-seek" played with the reader "which invites and thwarts all attempts to separate fact from fiction" (2003: 117-118), whereas Stefanie Harris would argue that the photographs and their unclear referents allow Sebald to communicate a particular relationship to the past: the presence of an irretrievable past in the photograph makes absence palpable (2001). Hemon, wanting to incorporate these horrific images into the text but without producing a totalising voyeuristic effect, would have found Sebald's techniques most beneficial, and Hemon has been forthright about Sebald's influence upon his own attempts at intermediality in photo-fiction/memoir and the necessity to transgress generic conventions. Sebald often commented on the uncategorisability of his own work, once noting in interview that: "[f]acts are troublesome. The idea is to make it seem factual, though some of it might be invented" (Atlas qtd. in Adams 2008). ${ }^{10}$ In interview, Hemon further clarifies this questioning of authenticity through the pretext of a docu-fiction comprised of ambiguous, often antiquated photographs:

Authenticity is a problematic concept in fiction. [...] Sebald addressed the problem of authenticity, of truth, by using photos in his books - they constantly fail as documents of the past, they can only signify loss. And pointedly, they interrupt the text. In Austerlitz, there are only nine paragraph breaks, I think, not counting the photos, which is to say that the photos interrupt the testimonial flow. I learned from Sebald. I wanted to create a situation in which writing would confront photographs. Language (and thus a work of literature) cannot authenticate itself but has to be authenticated through the reader's experience, whereas photographs are always - or at least in the predigital era - physical traces of physical objects. The question then becomes whether the story in my book becomes authentic because of the presence of photos or the photos become inauthentic because of the presence of the story. (Reyn 2010)

Similar to his inquiry into hyphenated, divided or either/or identities, Hemon underscores this critical need for overlap in forging the novel's image/text dynamics. Hemon turns to photographs whose blurriness, spectrality or otherwise poor quality offer little exactitude and definite record as they remain ambiguous, even the death pose portraits of Lazarus to a degree. Unlike Sebald though, Hemon adheres to a more traditional, ordered structure with the photographs constituting 
chapter headings where there are none, and yet, they perform different functions at different points, engaging the reader and serving as more than cues for what might transpire within the chapter (although some photographs do fulfil this role). More importantly, these photographs occupy the terrain between the chapters and their switches between history and memory, past and present, America and Europe. The ample space and gravity given to the photographs as interstices, as portals between one narrative and the other, are often through images which cannot be determined as belonging definitely to one time period or another. Both archival and contemporary images appear in black-and-white, encased in wide, black frames, centred in the page; this antiquated aesthetic accentuates the ethereal tone of each photograph regardless of actual content. They serve not only as a means to push the narrative forwards on a visual level, but also as a reminder that photographic images are always open to interpretation and by no means elicit authentication or truth, as so commonly perceived in everyday life. Rather, the images clear the space for fictionalisation and the narrative imagination by provoking the reader's own explanations.

To conclude, I would like to return to those tensions raised at this essay's opening regarding Hemon's noted aversion to autobiography and memoir. Hemon believes that any "autobio" affiliations must be crossed in order to reach the literary, and therefore, his work does not reject or subvert autobiography as method or genre, but rather demonstrates that neither can stand alone as intact categories. They must continually be complicated by that experiential overlap when identities shift, memories alter, and histories unravel. As I have argued, Hemon outlines this ethos for fiction through his particular employment of photographic images, emphasising how it prompts a writer beyond his or her personal affiliations towards seeing multiple "elsewheres" in the world:

The line between what happened and what could have happened is blurred, the border between the real and the imagined is rendered irrelevant. For the goal, and the challenge, is to make the reader trust his or her experience and imagination - as both are necessary to read a book - rather than measure the reality of the book by its distance from what is taken to be self-evident. Ideally, the reader would question his or her relation to the real, but not for the sake of my postmodern whimsy. Rather, the goal is to find ways to relate to the lives outside one's immediate experience, for which imagination is indispensable. (Reyn 2010)

For Brik the truth has little to do with the hopeful pursuit of facts he finds in his adopted country or along Lazarus's exodus map; hence, the novel begins with Brik's admission of what scarce details he knows against everything he does not: "The time and place are the only things I am certain of: March 2, 1908, Chicago. Beyond that is the haze of history and pain, and now I plunge:" (Hemon 2008: 1). As much as Brik proffers his quest as an archival and biographical one, he nonetheless clearly prepares the reader for the far more imaginative, subjective jour- 
ney to follow; this occurs in both time periods, as Hemon underscores the possibility that facts may actually disrupt or act as obstacles in such investigations into personal, subjective "truth": "The further away from Chicago [Brik gets], the less he understands. But he knows and imagines more. Sometimes facts get into the way of knowing" (Reyn 2010). Thus, by narrating and imaging these complex, overlapping spaces, Hemon reinforces the call for alternative life-writing practices first raised by Gilmore in The Limits of Autobiography. Hemon's approach to fiction has been and will continue to prove highly valuable for understanding and crossing both the national and aesthetic borders that have become increasingly fluid and unpredictable in our new millennium.

\section{Notes}

1 Menachem Kaiser, “The Exchange: Aleksandar Hemon” The New Yorker Online (9 June 2009).

This lack of testimonial presence or access is what likewise links Hemon to W. G. Sebald's prose and narrative strategies which labour to cope with this fissure in memory and history; although, in Sebald's case, it is a difference of temporality - of generation gap and postmemory - whereas for Hemon, it is more so a spatial or physical divide.

Averbuch is a real-life figure whose story is still something of a mystery and continues to be retold in historical accounts as to his possible connections to anarchist networks on the rise in Chicago at that time. Brik/Hemon does mention one leading book, The Accidental Anarchist (2005) by Walter Roth, which evidently fuelled much of Hemon's actual investigation into the affair.

When asked about current state of affairs as depicted in the book, Hemon prefers to understand the novel as speaking from a "post-Abu Ghraib" rather than post-9/11 context, given its more pressing concerns with immigrant identity, exclusion and assimilation expectations. In fact, Hemon situates this dilemma within the text itself by making the Abu Ghraib images the cause of one of Brik and Mary's worst arguments (2008: 189).

It should be noted that Hemon forced himself to learn and write in English, and began to write short fiction: "I wanted to record and remember my life, as I thought the war in Bosnia was going to erase us all" (Lee 2001-2: 204).

This opening cue is similar to his story "The Sorge Spy Ring" (The Question of Bruno) in which he includes a definition of "History" from the first edition of the Encyclopaedia Britannica (1769-1771) as epigraph: "History, a description or recital of things as they are, or have been, in a continued orderly narration of the principal facts and circumstances thereof. History, with regard to its subject, is divided into the History of Nature and the History of Actions. The History of Actions is a continued relation of a series of memorable events" (Hemon 2001: 39). In doing so, he sets up the inverse of everything in rewritten or fantastical version of historical record he presents with the following short story.

This kinship could be further traced in many of Barthelme's stories from the late 1960s and early 1970s such as "Indian Rising" or "Robert Kennedy Saved from Drowning" and how they inform the abrupt narrative switches in Hemon's The Question of Bruno collection. For a survey of these developments, see Timothy Dow Adams's recent article "Photography on the Walls of the House of Fiction" (2008), as well as his earlier book-length study of autobiography and photography's intersections, Light Writing and Light-Writing (2000). 
photographs and portraits to those which bear no apparent resonance on the plot or characters at present, or pictures of banal objects at times mentioned in the story, and rather grainy images of deserted buildings and landscapes. See Jonathan Long (W. G. Sebald: Image, Archive and Modernity, 2007), Carolin Duttlinger and Stefanie Harris for further consideration of Sebald's oeuvre.

10 As Mark Richard McCulloh has pointed out, this vantage point is what distinguishes Sebald's writing from other postmodern writers also interested in documentary fiction: "Sebald is close to Eco and Calvino, although he does not share their motivations in manipulating history and biography. Eco fictionalizes facts, whereas Sebald makes facts fictive [...] by binding them so deeply to the actual world" (2003: 86).

\section{References}

Adams, Timothy Dow (2000) Light Writing and Life Writing: Photography in Autobiography. Chapel Hill: University of North Carolina Press.

Adams, Timothy Dow (2008) 'Photography on the Walls of the House of Fiction'. Poetics Today 29(1), 175-195.

Baker, Deborah (2008) 'Aleksandar Hemon: Interview'. BOMB Magazine. August 2008. <http:// bombsite.com/issues/999/articles/3175>

Gilmore, Leigh (2001) The Limits of Autobiography: Trauma and Testimony. Ithaca: Cornell University Press.

Harris, Stefanie (2001) 'The Return of the Dead: Memory and Photography in W. G. Sebald's Die Ausgewanderten'. German Quarterly 74(4), 379-391.

Hemon, Aleksandar (2008) The Lazarus Project. New York: Riverhead Books.

Hemon, Aleksandar (2001) The Question of Bruno. London: Picador Press.

Johnson, Sarah Anne (2010) 'Interview with Aleksandar Hemon: Rescued by Language'. The Writer Magazine. May 2010. 18-21.

Kaiser, Menachem (2009) 'The Exchange: Aleksandar Hemon'. The New Yorker Online. 9 June 2009. <http://www.newyorker.com/online/blogs/books/2009/06/the-exchange-aleksander-hemon.html>.

Krauss, Rosalind (1993) The Originality of the Avant-Garde and Other Modernist Myths. Cambridge: MIT Press.

Lee, Don (2001-2) 'Postscript: Zacharis Award Winner Aleksandar Hemon' [Interview]. Ploughshares 27(4), 203-205.

Long, Jonathan (2003) 'History, Narrative, and Photography in W. G. Sebald's Die Ausgewanderten'. Modern Language Review 98(1), 117-137.

Long, Jonathan (2007) W. G. Sebald: Image, Archive and Modernity. New York: Columbia University Press.

McCulloh, Mark Richard (2003) Understanding W. G. Sebald. Columbia: University of South Carolina Press.

Reyn, Irina 'Exile on Any Street: In Conversation with Aleksandar Hemon'. Guernica. February 2010.

$<$ http://www.guernicamag.com/interviews/1532/not_melted_into_the_pot/>

Sebald, W. G. (1996) The Emigrants. Trans. Michael Hulse. London: Harvill Press.

Wood, James (2008) 'The Unforgotten: Aleksandar Hemon's Fictional Lives'. The New Yorker. 28 July 2008. 82. 
Wendy Ward is a Lecturer in the School of English, Drama \& Film at University College Dublin and has recently completed her dissertation in American Studies. Her doctoral research focused on mid- to late-twentieth century American fiction writers and their engagements with visual culture. She writes on a variety of interdisciplinary subjects, including twentieth-century American literature and photography, cultural studies, intermediality and photo-fiction, Irish-American contemporary fiction and film.

Address: Dr. Wendy Ward, The Clinton Institute for American Studies, University College Dublin, Belfield House, Dublin 4, Ireland. [email: wendy.ward22@gmail.com] 
